\title{
Spatial dynamics of agricultural land in Banyuasin Regency, South Sumatera: Its opportunities and threats
}

\author{
Intan Pujawati ${ }^{1}$, Ellen Suryanegara ${ }^{1}$, Munawaroh $^{1}$, and Aninda W. Rudiastuti ${ }^{1 *}$ \\ ${ }^{1}$ Geospatial Information Agency, The Republic of Indonesia, Jl. Raya Bogor Km 46, Cibinong, West \\ Java, 16911, Indonesia
}

\begin{abstract}
The availability of agricultural land, especially paddy fields, is an inseparable part of efforts to maintain national food security and engage SDGs' second goal. Changes in land cover/land use can occur due to social, political, economic, cultural, natural, and technological factors. Geographic Information Systems (GIS) operate as a tool to comprehend the changes related to the driver's factors. The purpose of this study was to examine the spatial dynamics of paddy land cover in the Banyuasin Regency for more than 2 decades using the Markov Chain approach and to analyze the inhibiting and supporting factors in developing paddy farming in the region. The inhibiting factor discussed in this study is the potentiality of floods in paddy fields. The results showed that paddy fields in Banyuasin Regency experienced the widest decrease of 2,863.80 hectares and encountered the largest increase of 14,463.45 hectares in 1990-2003. The threat factor also influenced changes in the area of agricultural land in the form of inundation. The flood inundation crisis peaked in 2010, where 832.58 hectares out of $164,562.37$ hectares of paddy field were flooded. However, the potency in developing lowland rice farming on swamps in Banyuasin Regency is considerably beneficial. This can be examined from the value of Revenue-Cost Ratio (R/C Ratio), averaging 3.65, and BenefitCost Ratio (B/C Ratio) of 2.65 with an average production of 5-7 tons/hectares/season.
\end{abstract}

\section{Introduction}

Paddy field conversion is a serious threat to national food security, considering that land conversion is difficult to avoid, while the impacts on food problems are permanent, cumulative, and progressive [1]. Food production has been dominated by rice yields planted in paddy fields compared to rice planted in dry-fields [2]. As an illustration, in 2014, national paddy fields produced 70,846,465 tons of grain [3] produced from 8,111,593 hectares of rice harvested areas in Indonesia [4]. According to [2], agricultural land has social, economic, and environmental benefits. Changes in agricultural land-use can have

\footnotetext{
* Corresponding author: aninda.wisaksanti@big.go.id
} 
serious impacts on food production, the physical environment, and the agricultural community's welfare. These changes can lead to a positive implication developed by the land's planning and carrying capacity and lead to negative implications such as water pollution, air, local climate change, and loss of biodiversity [5].

Banyuasin Regency is the largest national rice granary in South Sumatera Province. The potency of agricultural land for food crops in the Banyuasin Regency reaches 1,170,022 hectares, consisting of 204,125 hectares (17\%) of tidal paddy fields and 96,5897 hectares $(83 \%)$ of land area. Types of rice production in the Banyuasin Regency include upland paddy field, tidal paddy field, and lebak (swamp) paddy field. Rice produced in the tidal paddy field became the largest production with a total production of $682,786.8$ tons in 2010. The smallest production was coming from the Lebak paddy field, which amounted to 107,708.1 tons [6]. On the other hand, excessive surface runoff can cause flooding, inundation, and damage to agricultural land [7]. The flood on agricultural land reduces the productivity of paddy fields, which impacted the food stock stability. Therefore, it is necessary to detect the area of flooded paddy fields. In the South Sumatera region, flooding is a periodic disaster that often strikes. Flood disasters occurred in 2000, 2010, 2015, and 2016. Kompas in 2011 reported that the main cause of frequent flooding was the decrease in the number of swamps in Palembang due to the conversion of swamps to built-up areas [8].

Besides the threat of sustainability of agricultural land, it is important to realize that the potential of Lebak swamps can be utilized to increase the additional amount of national rice production, although its role is currently quite limited. The Ministry of Agriculture noted that from the total national production, about 62.56 million tons harvested unhusked rice (GKP) of total national production, Lebak swamps' contribution was only $1-1.5 \%$. This means that grain production from swamps is around 600,000-700,000 tons per year. Lebak swamps widely spread in Banyuasin Regency, particularly in the Rambutan Village, but most of it has not been maximally utilized.

Based on the description above, the research is carried out to examine the spatial dynamics of paddy land cover in the Banyuasin Regency for more than two decades using the Markov Chain approach and analyze the inhibiting and supporting factors in developing paddy farming in the region. The inhibiting factor discussed in this study is the potentiality of floods on agricultural land, especially paddy fields.

\section{Method}

\subsection{Spatial analysis}

This research was conducted in August 2017, and Banyuasin Regency in South Sumatera was chosen as the study area. Geographically, it located between $1^{\circ} 37^{\prime} 32.12^{\prime \prime}-3^{\circ} 09^{\prime} 15.03^{\prime \prime} \mathrm{S}$ and $104^{\circ} 02^{\prime} 21.79^{\prime \prime}-105^{\circ} 33^{\prime} 38.5^{\prime \prime}$ E. Data used in this study given in Table 1.

Table 1. Data sources and purposes.

\begin{tabular}{|l|l|c|l|}
\hline \multicolumn{1}{|c|}{ Data } & \multicolumn{1}{|c|}{ Sources } & Period & \multicolumn{1}{c|}{ Analysis } \\
\hline Landsat Imagery & USGS & $2000,2010,2015$ & NDWI \\
\cline { 1 - 3 } $\begin{array}{l}\text { Administration } \\
\text { Boundary, River, etc }\end{array}$ & South Sumatera & 2014 & - NDWI \\
\cline { 1 - 1 } Landuse & & & - Markov \\
\cline { 1 - 1 } Paddy field area & $\begin{array}{l}\text { One Map of Paddy field } \\
\text { Chain }\end{array}$ \\
\cline { 3 - 4 } & $(1: 50.000)$ & 2014 & Flood \\
& Topographic Map (1:50.000) & 2014 & Analysis \\
& & (NDWI) \\
\hline
\end{tabular}




\begin{tabular}{|l|l|l|l|}
\hline & Landuse map & $1990-2016$ & \\
\hline $\begin{array}{l}\text { Southern Oscillation } \\
\text { Index (SOI) }\end{array}$ & $\begin{array}{l}\text { National Center for } \\
\text { Environmental Information }\end{array}$ & $2000-2015$ & Climate \\
\hline
\end{tabular}

\subsection{Land Change Modeler (LCM)}

This research used The Land Change Modeler (LCM) module, a raster-based spatial data processing software with the Markov Chain. The Markov Chain algorithm (Equation 1) can predict future events using probabilities that have arisen in the past and present [9]. In statistical probability theory, the Markov process analyzes phenomena that change with time at random for certain circumstances. According to [10], Markov Chain Stationer presumed if $\mathrm{Xn}=\mathrm{i}$, then the process is said to be in state-I, so that:

$$
\begin{aligned}
P\left(X_{n-1}\right) & =\frac{j}{X_{n}=1, X_{n-1}=i_{n-1}, \ldots, X_{1}=i_{1}, X_{n}=i_{n}} \\
& =P\left(\frac{X_{n+1}=j}{X_{n}=1}\right) \\
& =P_{i j}
\end{aligned}
$$

In Equation 1, the conditional opportunity for future events $\left(X_{n}+1\right)$ only depends on the current event $X_{n}$. This is called Markovian (Equation 2) since the opportunity starts nonnegatively and the process must make a transition to various states, then:

$$
\mathrm{p}_{\mathrm{ij}} \mu 0, \quad \mathrm{i}, \mathrm{j} \mu 0 ; \sum_{j=1} p_{i j}=1, \mathrm{i}=0,1,2, \ldots
$$

Estimation for $\mathrm{p}_{\mathrm{ij}}$ carried on by using the maximum likelihood method, as written in Equation 3.

$$
p_{i j}=\frac{\left(a_{i j}\right)}{\sum_{i} a_{i j}}
$$

$\mathrm{a}_{\mathrm{ij}}=$ sum of movement from state-i to state- $\mathrm{j}$ in a certain period of observation.

The land change modeling is carried out using the LCM application with three stages [11]:

1. Change analysis: Analysis implemented to land cover data from 1990 to 2003.

2. Transition Potential: to predict potential locations that change. The prediction resulted in a Potential Transition Map with a value between 0-1. When closer to the highest value (1) means the location has a vast possibility to change to other uses.

3. Modeling and prediction of paddy field: use the Markov Chain method with the assumption that changes occurred in the future have similar patterns and opportunities to the pattern of changes that occur during the period of data used. The validation test measured using the Kappa Index of Agreement [12].

\subsection{Flood analysis (NDWI)}

Utilization of remote sensing data such as MODIS, Landsat, SPOT, DEM, and TRMM images to monitor flood events, especially in paddy fields are common [13-15], as well as with modeling results data [16]. Normalized Difference Water Index (NDWI) has 
dimensionless properties and varies between -1 to +1 , depending not only on the leaf water content but also on the type of vegetation and cover. The high value on NDWI corresponds to the high water content and high fraction closure of vegetation, and vice versa for the low value. Mcfeeters [17] extracted NDWI values using green and near-infrared (NIR) bands (Equation 4), e.g:

$$
\text { NDWI }=(\rho \text { GREEN }-\rho N I R) /(\rho \text { GREEN }+\rho N I R)
$$

The utilization of modified NDWI [17] during floods tends to increase both for vegetation or open field. Image transformation applied at all remote sensing images, during (NDWIpre) and after (NDWIpost) flood events. The changes between pre-flood and post events act as indicators of flooded pixels (Equation 5).

$$
\Delta \mathrm{NDWI}=\text { NDWI pre-NDWI post }
$$

(5)

\subsection{Socioeconomic analysis}

Qualitative data collected using purposive sampling to emboss the socioeconomics aspect of research. The primary data collection was carried out by in-depth interviews using structured interview guidelines for representatives of the Association of Farmers Groups. They own Lebak swamp in the Rambutan Regency, Banyuasin Regency. According to [18], descriptive research attempts to describe why a social phenomenon arises. This analysis tries to provide a description of the potential and opportunities for developing swamp farming in the Rambutan Regency and the characteristics of lowland rice farming in Lebak swamp with socioeconomic analysis using the calculation of B/C Ratio (Benefit-Cost Ratio) and R/C Ratio (Revenue-Cost Ratio) as written in Equation 6 and 7.

$$
B / C \text { Ratio }=\frac{\text { Benefit }(B)}{\text { Total Cost }(T C)}
$$

If $\mathrm{B} / \mathrm{C}$ ratio $>1$ then worth for economic endeavor, If $\mathrm{B} / \mathrm{C}$ ratio $<1$ then ill-starred

$$
R / C \text { Ratio }=\frac{\text { Total Revenue }(R)}{\text { Total Cost }(T C)}
$$

If $\mathrm{R} / \mathrm{C}>1$ = economically beneficial

\section{Results and discussion}

Along with the rapid development in various sectors, paddy fields experienced various dynamics. In some areas, such as in Banyuasin Regency, the area of paddy fields has increased. This is in line with [19], which states that land-use changes in South Sumatera Province were not as big as this, which occurs in Java. Based on the research, in the range of two decades (1990-2015), there has been an increase in paddy fields by $5.03 \%$ or $60,863.87$ hectares. The addition of paddy fields is largely spread in the south to the southeastern region of the Banyuasin Regency, where the area is affected by the Musi River flow. In general, the typology of paddy fields in South Sumatera Province is characterized by the extent of tidal, lowland, and rainfed paddy fields compared to the area of irrigated paddy fields [19]. This is directly proportional to the research results showing the expansion of tidal-type paddy fields around the banks of the Musi River, which is the source of irrigation. The data tabulation results of paddy fields at the study sites in 1990, 2003, and 2015 are presented in Table 2. 
Table 2. Area of Paddy Fields and Non-Paddy Fields in 1990, 2003, and 2015.

\begin{tabular}{|c|c|c|c|}
\hline \multicolumn{2}{|c|}{ Land-Cover Class } & Paddy Fields & Non- Paddy Fields \\
\hline $\mathbf{1 9 9 0}$ & Area (ha) & $152,964.50(12.64 \%)$ & $1,056,770.48(87.36 \%)$ \\
\hline $\mathbf{2 0 0 3}$ & Area (ha) & $164,562.37(13.60 \%)$ & $1,045,172.62(86.40 \%)$ \\
\hline $\mathbf{2 0 1 5}$ & Area (ha) & $213,828.37(17.43 \%)$ & $1,012,693.59(82.57 \%)$ \\
\hline
\end{tabular}

The addition of paddy fields from 1990, 2003, and 2015 cannot be separated from the Regional Regulation of Banyuasin Regency No. 24 of 2012 concerning Protection of Sustainable Food Agriculture Land. Out of 15 regencies and cities in South Sumatera, only two regencies have special regulations related to protecting agricultural land for food. These Regency include Ogan Komering Ulu Timur and Banyuasin Regency [20]. The Banyuasin regional government has carried out strict protection and prohibition of converting sustainable agricultural land, except in the context of land acquisition for public purposes or natural disasters. The government was also obliged to protect and empower farmers, farmer groups, farmer cooperatives, and farmer associations. This is what supports the development of the agricultural sector in the Banyuasin Regency.

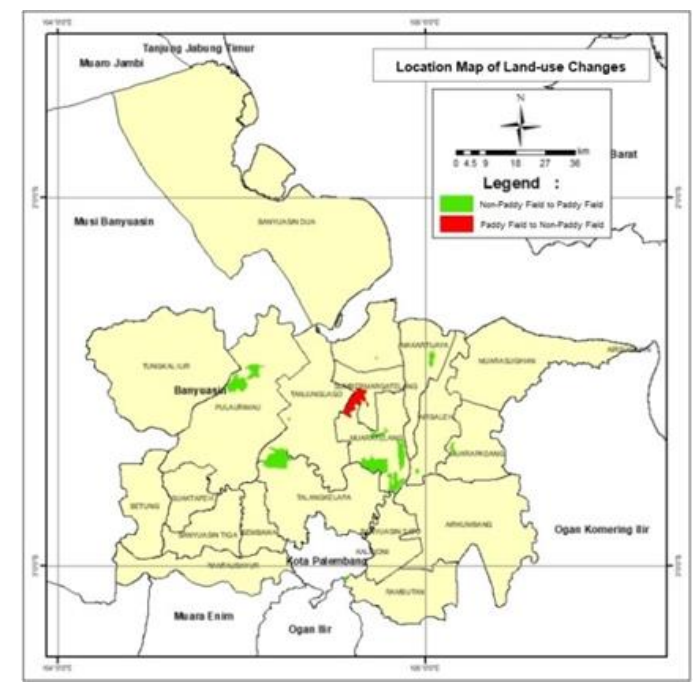

Fig. 1. Location Map of Land-use Changes Based on Modeling Simulations for Non-Paddy fields Land-cover in 1990 and 2003.

The simulation results of modeling paddy fields between 1990 and 2003 showed an increase and decrease in land area for paddy and non-paddy field classes. The increase in paddy fields was $14,463.45$ hectares, while the change in paddy fields to non-paddy fields was $2,863.80$ hectares. The location map of land-use changes of paddy and non-paddy fields results from this stage's modeling, presented in Fig. 1. The simulation results show the dominance of the change in non-paddy fields to paddy fields. Non-paddy fields which are turned into paddy fields are scattered in the Pulaurimau, Tanjunglago, Talangkelapa, Muaratelang, Makartijaya, Airsaleh, Banyuasin Dua, and Muarapadang. At the same time, paddy fields that are converted to non-paddy fields are found in Sumbermargatelang and Muaratelang Regency. Modeling of paddy field changes was done by combining the driving factors, i.e., the distance from the road and the river. Roads are an economic driving factor of land-use change, mainly due to the high land-rent area close to the road [11]. Road access in an area tends to be a driving factor in the development of developed land, with 
irreversible land-use changes. River flow is a driving factor in terms of the physical condition of the land. This is closely related to the function of the river as a source of irrigation for paddy fields. The typology of tidal paddy fields and Lebak swamps shows a strong correlation between rivers and agricultural activities in Banyuasin Regency. At the prediction stage, spatial data analysis of land-cover/land-use tests from 1990 to 2003 was conducted for the 2015 predictions. The purpose of this test is to validate the predicted results of the 2015 land-use change map, using a 2015 land-cover map.

\subsection{Spatial analysis of flood event}

Landsat imageries derived from the rainy season in 2005-2015 generally show a significant difference in NDWI results (Figure 2). In 2015, it showed no inundation in Banyuasin Regency, whereas in 2005, the inundation in paddy fields was more widespread, especially in the northern area of the Banyuasin Regency. The inundation peak in 2010, which correlates with the weather anomaly, La Nina.

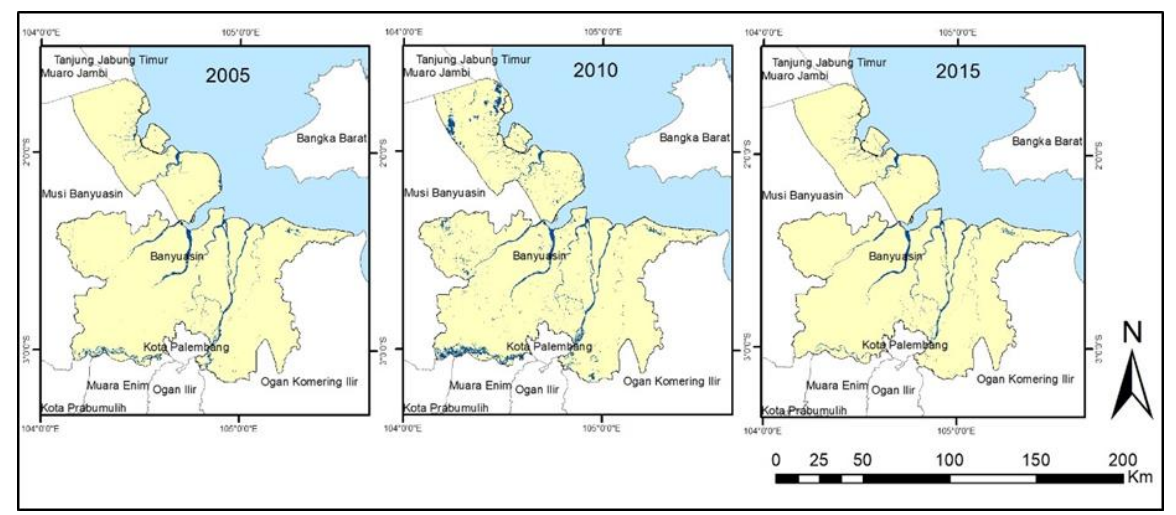

Fig. 2. NDWI Results Based on Multitemporal Landsat Imagery in 2005, 2010, and 2015 in Banyuasin Regency, South Sumatera.

El Nino and La Nina are the dynamics of climate anomalies in the Pacific Ocean characterized by rising sea surface temperatures (SST) in the central and eastern equatorial regions. When El Nino occurs, the rising of SST will spread until it rises upward (convection), and low-pressure areas form on the west coast of Peru-Ecuador. As a result, the wind that heads to Indonesia carries only a little moisture and resulting in a long dry season [21]. Contrary, La Nina brings the impact of high rainfall and floods, which can cause food insecurity due to crop failure [22]. The La Nina event results in excessive water availability and causes flooding to experience crop failure. Both of these climate anomaly events are known to have caused damage to rice plants in Indonesia [23]. Figure 3 shows fluctuations in Southern Oscillation Index (SOI) data where the positive value correlates with the La Nina episode, wherein 2010 the index has shown was higher than in 2005 and 2015. The total area of paddy fields in the Banyuasin Regency in 2010 was estimated to reach $\pm 164,562.37$ hectares, wherein around 832.58 hectares of paddy fields are mostly types of Lebak paddy fields, was flooded due to flooding in 2010 (Figure 4). 


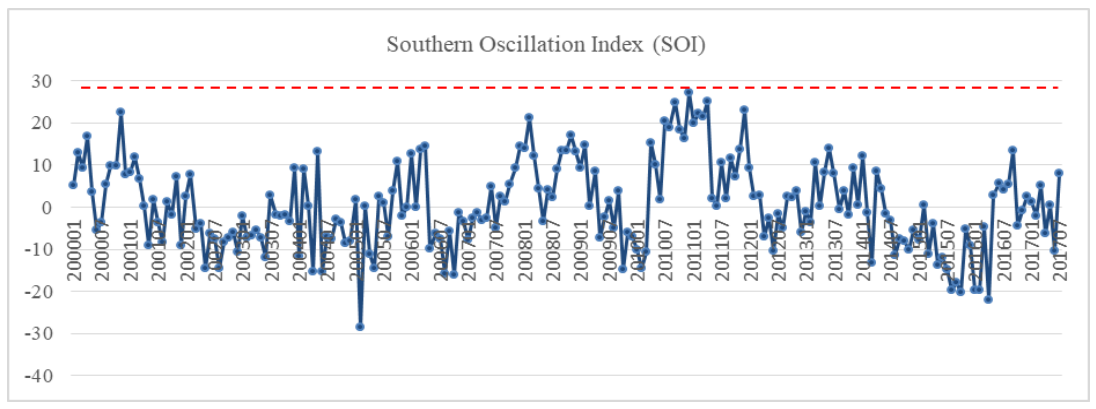

Fig. 3. Southern Oscillation Index (SOI) for the period 2000-2016.

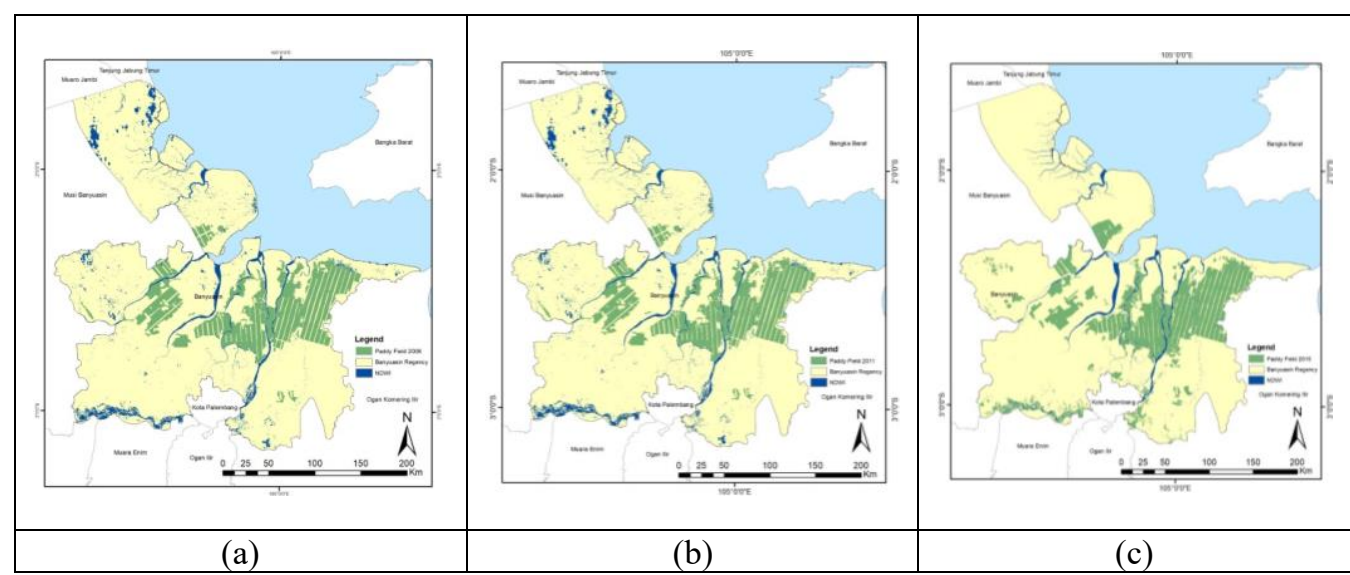

Fig. 4. Distribution of inundation on paddy fields in Banyuasin Regency in (a) 2005 (627.77 hectares), (b) 2010 (832.58 hectares), and (c) 2015 (138.67 hectares).

\subsection{Socioeconomic analysis of agriculture land productivity}

Banyuasin Regency has a strategic geographical location and has been divided into 19 regencies. The topography of Banyuasin consists of $80 \%$ plain area (exist as tidal swamps and Lebak swamps). In this region, the water flow pattern, especially in a swamp and the tidal area, is generally rectangular [24]. According to the Central Bureau of Statistics in 2016, it can be observed that the rambutan sub-Regency has the highest unproductive land (6,041 hectares). However, not all types of swamps are suitable for agriculture. Only swampland was overgrown with shrubs that are ecologically suitable for agricultural cultivation activities.

Based on the Banyuasin Central Bureau of Statistics, the number of citizens who work as farmers is 25,961 people [24]. Specifically, in Gelebak Village, a total of 1,428 people are living as farmers. Based on the interview results, it is recognized that 3-20 people are involved as laborers in the production process in the Lebak swamp farming. This is proof that Lebak swamp farming could absorb a large number of the labor force. The average land occupancy by each farmer is around 1-2 hectares. One area that has a majority of the citizen as Lebak swamp farmers is in Gelebak Dalam Village. The Lebak swamp in Gelebak Dalam Village is divided into Lebak Dalam, Lebak Tengahan, and Lebak Dangkal. Those three types of Lebak are characterized by different water depths and periods of planting. Lebak only produced once a season in a year. 


\subsection{Business feasibility analysis of lebak swamp farming}

Like any other business, agricultural production business, in its implementation to produce crop, income, and profits, allocation of budget (cost) is required. Investment costs include the cost of purchasing land, building a hut/guardhouse, and agricultural equipment. Variable costs consist of purchasing seeds, fertilizer, grass medicine, labor wage, and fuel. Fixed costs specifically for land tax and land retribution. The results showed that the Lebak swamps paddy field in Banyuasin Regency was considered sufficient to be developed further with wide market potential and could increase national rice production. The calculation (Table 3) resembles that the value of revenue to cost ratio $(\mathrm{R} / \mathrm{C}$ ) averaged 3.65, and the $\mathrm{B} / \mathrm{C}$ ratio is 2.65 , with an average production of 5-7 tons/ha/season. This indicates that the Lebak swamp farming business in Banyuasin Regency is feasible, and the business is also considered efficient/profitable. The $\mathrm{R} / \mathrm{C}$ ratio value shows that every additional cost of Rp. 1,000 will be obtained an additional revenue of Rp. 3,650. Consequently, the agriculture business can be assumed to be very feasible to be cultivated and developed further.

Table 3. Business feasibility analysis of lebak farming in Banyuasin.

\begin{tabular}{|l|l|l|l|l|l|}
\hline No & Description & Unit & Amount & Price & Total/ Year (Rp) \\
\hline 1 & Average Investment Cost/Year & & & & 369,167 \\
\hline 2 & Average Variable Costs/Year & & & & $5,019,500$ \\
\hline 3 & Average Fixed Cost/Year & & & & 30,000 \\
\hline 4 & Average Revenue / Year (Rp) & & & & $19,801,250$ \\
\cline { 2 - 6 } & a. Personal consumption & $\mathrm{kg}$ & 1,000 & - & - \\
\cline { 2 - 6 } & b. Grain & $\mathrm{kg}$ & 833 & 4,000 & $3,332,000$ \\
\cline { 2 - 6 } & c. Milled Rice & $\mathrm{kg}$ & 2,196 & 7,500 & $16,469,250$ \\
\hline Total Cost (Rp) & $5,418,667$ & \\
\hline Total Income (Rp) & $14,382,583$ \\
\hline R/C RATIO & 3.65 \\
\hline B/C RATIO & 2.65 & \\
\hline
\end{tabular}

Changes in paddy fields in Banyuasin Regency cannot be avoided due to the growing demand for other land use. However, this will not be a significant obstacle if the potential of lowland paddy fields (Lebak swamp) as a new food center is well optimized. Economically, rice production in lowland paddy fields promising good profits for the surrounding community. Since the Lebak swamps are always affected by the river tides, the flood event is expected to be anticipated and even possible to modify the land so that it can be used as a source of irrigation for lowland paddy fields.

\section{Conclusion}

Paddy fields in Banyuasin Regency experienced the widest decrease of 2,863.80 hectares and encountered the largest increase of 14,463.45 hectares in 1990-2003. The inundation also influenced changes in the area of agricultural land. The flood crisis peaked in 2010, where 832.58 hectares out of 164,562.37 hectares of paddy fields in the Banyuasin Regency was flooded. However, the potential for developing lowland rice farming in Lebak swamps in Banyuasin Regency is considerably beneficial. Based on the farm business analysis, rice production is profitable and feasible. This can be examined from the value of Revenue-Cost Ratio (R/C Ratio), averaging 3.65, and Benefit-Cost Ratio (B/C Ratio) of 2.65 with an average production of 5-7 tons/hectares/season. Further, the potential of lowland paddy 
fields (Lebak swamp) as a new food center is very promising. Economically, rice production in lowland paddy fields foretells good profits for the surrounding community.

\section{References}

1. B. Irawan, Konversi Lahan Sawah: Potensi Dampak, Pola Pemanfaatannya, dan Faktor Determinan. Forum Penelitian Agro Ekonomi, 23(1), 1-18 (2005)

2. S.I. Hidayat, Analisis Konversi Lahan Sawah di Provinsi Jawa Timur. Journal of Social and Agricultural Economics, 2(3), 48-58 (2008)

3. Central Bureau of Statistics, Produksi Padi Menurut Provinsi (ton), 1993-2015 (2016) https://www.bps.go.id/linkTableDinamis/view/id/865

4. Central Bureau of Statistics, Luas Lahan Sawah Menurut Provinsi (ha), 2003-2014 (2017) https://www.bps.go.id/linkTableDinamis/view/id/895

5. D. Hu, G. Yang, Q. Wu, H. Li, X. Liu, X. Niu, Z. Wang, \&, Q. Wang, Analyzing land use changes in the Metropolitan Jilin City of Northeastern China Using Remote Sensing and GIS. Sensors, 8, 5449-5465 (2008)

6. Workgroup of PTGL-EHKB Banyuasin Regency, Perencanaan Tata Guna Lahan untuk Mendukung Pembangunan Rendah Emisi di Kabupaten Banyuasin, Pangkalan Balai, Kabupaten Banyuasin, Provinsi Sumatera Selatan. Regional Development Planning Agency (Bappeda), Banyuasin Regency (2016)

http://simbangda.banyuasinkab.go.id/documents/547

7. U. Kurnia, Prospek pengairan pertanian tanaman semusim lahan kering. Jurnal Litbang Pertanian, 23(4), 130-138 (2004).

8. Kompas, Banjir Sumsel semakin sering terjadi (2011) http://nasional.kompas.com/read/2011/02/22/18051725/

9. H. Januarto, Algoritma Markov Chain untuk Pembentukan Gatra pada Gendhing Lancaran Slendro Pathet Manyura (Unpublished undergraduate's thesis) (Universitas Dian Nuswantoro, Semarang, 2016)

10. E. Abdurachman, Konsep Dasar Markov Chain serta kemungkinan penerapannya di Bidang Pertanian. Jurnal Informatika Pertanian, 8, 499-505 (1999)

http://www.litbang.pertanian.go.id/warta-ip/pdf-file/edi.pdf

11. S.H. Kubangun, O. Haridjaja, \& K. Gandasasmita, Model Perubahan Penutupan/Penggunaan Lahan untuk Identifikasi Lahan Kritis di Kabupaten Bogor, Kabupaten Cianjur, dan Kabupaten Sukabumi. Majalah Ilmiah Globë, 18(1), 21-32, (2016)

12. D.P. Prabowo, S. Bachri, \& B.S. Wiwoho, Prediksi Perubahan Penggunaan Lahan dan Pola Berdasarkan Citra Landsat Multiwaktu dengan Land Change Modeler (LCM) Idrisi Selva 17: Studi Kasus Sub-Das Brantas Hulu, Jurnal Pendidikan Geografi, 22(1), 32-47 (2017)

13. N. Febrianti, \& D. Domiri, Analisis Potensi Banjir di Sawah Menggunakan Data Modis dan TRMM (Studi Kasus Kabupaten Indramayu). Jurnal Penginderaan Jauh, 9(1): 17 (2012)

14. N.S. Haryani, A. Zubaidah, D. Dirgahayu, H.F. Yulianto, \& J. Pasaribu, Flood Hazard Model Using Remote Sensing Data in Sampang District. Jurnal Penginderaan Jauh, 9(1), 52-66 (2012)

15. A. Zubaidah, D. Dirgahayu, , J.M. Pasaribu \& B. Lingkungan, Pemantauan Kejadian Banjir Lahan Sawah Menggunakan Data Penginderaan Jauh (Modis) Di Provinsi Jawa Timur dan Bali. Jurnal Ilmiah Widya, 1, 78-84, (2013)

16. M.A. Marfai, D. Mardiatno,A. Cahyadi, F. Nucifera, \& H. Prihatno, Pemodelan Spasial Bahaya Banjir Rob Berdasarkan Skenario Perubahan Iklim dan Dampaknya di Pesisir Pekalongan. Jurnal Bumi Lestari, 13(2), 244-256 (2013) 
17. S.K. Mcfeeters, The use of the Normalized Difference Water Index (NDWI) in the delineation of open water features. International Journal of Remote Sensing, 17(7), 1425-1432 (1996)

18. K.S. Newman, C. Fox, W. Roth, J. Mehta, \& D.J. Harding, Rampage: The social roots of school shootings, Basic Books, New York (2008)

19. M. Iqbal, Alih Fungsi Lahan Sawah dan Strategi Pengendaliannya di Provinsi Sumatera Selatan, ICASEPS Working Paper No. 92. Pusat Analisis Sosial Ekonomi dan Kebijakan Pertanian (PSE-KP), Badan Penelitian dan Pengembangan Pertanian, Bogor (2007)

20. Kompas, Baru Dua Kabupaten di Sumsel Lindungi Lahan Pertanian (2012) https://sains.kompas.com/read/2012/12/05/2308057/Baru.Dua. Kabupaten.di.Sumsel.Lindungi.Lahan.Pertanian

21. S. Safitri, El Nino, La Nina dan Dampaknya terhadap Kehidupan di Indonesia. Jurnal Criksetra, 4(8), 153-156 (2015)

22. T.H.K. Bayong, A. Lubis, I. Juaeni, Ruminta, \& S.W.B. Harijono, Dampak Variasi Temperatur Samudera Pasifik dan Hindia Ekuatorial Terhadap Curah Hujan di Indonesia. Jurnal Sains Dirgantara, 5(2), 83-95 (2008)

23. A.W. Utami, Jamhari, \& S. Hardyastuti, El Nino, La Nina, dan Penawaran Pangan di Jawa, Indonesia. Jurnal Ekonomi Pembangunan, 12(2), 257-271 (2011)

24. Banyuasin Central Bureau of Statistics. Kecamatan Rambutan dalam Angka Tahun 2017 (2017) https://banyuasinkab.bps.go.id/ 